\title{
Molecular docking study and antiviral evaluation of 2-thioxo-benzo[g] quinazolin-4(3H)-one derivatives
}

\author{
Rashad Al-Salahi', Hatem A. Abuelizz ${ }^{1}$, Hazem A. Ghabbour ${ }^{1}$, Rabab El-Dib ${ }^{2,3}$ and Mohamed Marzouk ${ }^{1,4^{*}}$
}

\begin{abstract}
Background: The persistent appearance of viral strains that causes a resistant viral infection has led to continuous trials for the design and development of novel antiviral compounds. Benzoquinazoline compounds have been reported to exhibit an interesting antiviral activity. This work aims to study and evaluate the antiviral activity of a newly prepared 2-thioxo-benzo[g]quinazolin-4(3H)-one series against herpes simplex (HSV-1 \& 2) and coxsackievirus (CVB4).

Methods: The antiviral activity was performed using the MTT assay, in which Vero cells (obtained from the American Type Culture Collection, ATCC) were propagated in fresh Dulbecco's Modified Eagle's Medium (DMEM) and challenged with $10^{4}$ doses of the virus. Thereafter, the cultures were treated simultaneously with two-fold serial dilutions of the tested compound and incubated at $37^{\circ} \mathrm{C}$ for $48 \mathrm{~h}$. Molecular docking studies were done on the CVB4 2A proteinase enzyme using Molegro Virtual Docker software.
\end{abstract}

Results: The cytotoxicity $\left(\mathrm{CC}_{50}\right)$, effective concentration $\left(\mathrm{EC}_{50}\right)$ and the selectivity index (SI) values were determined. Based on their $\mathrm{EC}_{50}$ values, a number of the investigated compounds demonstrated weak to moderate activity relative to their parents. Accordingly, compounds 5-9, 11, 15-18, 21, 22, 24, 25, 27 and $\mathbf{2 8}$ were active against CVB4, and compounds $\mathbf{5}$ and $\mathbf{2 4}$ were active against HSV-1 and 2 in comparison to ribavirin and acyclovir, which were used as reference drugs.

Conclusion: The obtained results gave us some useful insights about the characteristic requirements for future trials to build up and design more active and selective antiviral 2-thioxo-benzo[g]quinazolin-4(3H)-one agents.

Keywords: 2-Thioxo-benzo[g]quinazolines, HSV, Coxsackievirus, Molecular docking, Ribavirin

\section{Background}

Herpes simplex (HSV-1 \& 2) and Coxsackie B4 (CVB4) viruses belong to the alphaherpesvirinae and picornaviridae families, respectively. In contrast to HSV-1 and 2 which classified as enveloped double-stranded DNA viruses, CVB- 4 is non-enveloped RNA viruses. They are common human pathogens and considered a significant worldwide health concern [1-3]. A relatively wide range of diseases, ranging from asymptomatic, mild infections to serious illnesses, are caused by these viruses $[4,5]$. In addition, infections by CVB4 have also been known to

\footnotetext{
*Correspondence: mohmarzouk@ksu.edu.sa

1 Department of Pharmaceutical Chemistry, College of Pharmacy,

King Saud University, P. O. Box 2457, Riyadh 11451, Saudi Arabia

Full list of author information is available at the end of the article cause aseptic meningitis, encephalitis, pleurodynia, myocarditis, and pericarditis [5].

Viral infectious diseases pose a major challenge for modern medicaments because the viruses have high mutation rates, which allow them to escape immune systems and become resistant to the traditional antiviral drugs [6-10]. Furthermore, although the antiviral drugs for diseases caused by several types of viruses such as herpes are available clinically, but the high prevalence of viral infections for which there are no specific treatments or the continuous appearance of new resistant viral strains are serious problems. This make the task of the development of new novel antiviral agents is essential [10]. 
Recently, we have reported the biological activity of some prepared triazoloquinazolines against herpes simplex (HSV-1 \& 2) and CVB4. However, a number of these prepared compounds were found to possess remarkable and significant antiviral activity [11-13]. Furthermore, synthetic chemistry has shown that benzoquinazoline is a valuable precursor for elaborating many structurally diverse bioactive molecules, particularly as influenza $\mathrm{H} 5 \mathrm{~N} 1$ and $\mathrm{H} 1 \mathrm{~N} 1$ antiviral agents [14-17]. In addition, some 2-aminobenzo[de]-isoquinoline-1,3-diones have been reported as antiherpetic agents [11].

In view of these evidences and an extension of our ongoing research on benzoquinazolines chemistry, we herein report the antiviral evaluation of a new series of 2-thioxo-benzo[ $g]$ quinazolin-4(3H)-one derivatives against HSV-1, HSV-2 and CVB4 viruses.

\section{Results and discussion}

We previously reported our findings regarding the antiviral activity of isoquinazoline and triazoloquinazoline derivatives. The results suggested that quinazolines can be good platform for designing a new antiviral agent [11-13]. Here, we are reporting the results of an antiviral investigation for a new series of 2-thioxo-benzo $[g]$ quinazolines 1-28 (Table 1 and Scheme 1) [18]. The evaluation of the synthesized compounds 1-28 against HSV-1, HSV-2 and CVB4 was assessed in vitro using an MTT assay. Their cytotoxic effects were also evaluated. Results obtained from this screening showed that most of the compounds demonstrated antiviral activity, which ranged from weak through moderate to high effects, based on $\mathrm{EC}_{50}$ and SI values relative to their parent and reference drugs (Table 2). In accordance to the statistical analyses and in terms of SI as a marker for

Table 1 Synthesized 2-thioxo-benzo[g]quinazolines (7-28)

\begin{tabular}{|c|c|c|c|c|c|}
\hline CPs & $\mathbf{R}$ & $R_{1}$ & $\mathrm{CPs}$ & $\mathbf{R}$ & $\mathrm{R}_{\mathbf{1}}$ \\
\hline 7 & Butyl & Ethyl & 18 & Allyl & 3-methoxybenzyl \\
\hline 8 & Butyl & Allyl & 19 & Allyl & 4-chlorobenzyl \\
\hline 9 & Butyl & Benzyl & 20 & Allyl & 2-morpholinoethyl \\
\hline 10 & Butyl & 3-methoxybenzyl & 21 & Allyl & $\begin{array}{l}\text { 3-(phthalimido-2-yl) } \\
\text { propyl }\end{array}$ \\
\hline 11 & Butyl & 4-chlorobenzyl & 22 & Phenyl & Ethyl \\
\hline 12 & Butyl & 4-cyanobenzyl & 23 & Phenyl & Allyl \\
\hline 13 & Butyl & 2-piperidinoethyl & 24 & Phenyl & 3-cyanobenzyl \\
\hline 14 & Butyl & 2-morpholinoethyl & 25 & Phenyl & 4-chlorobenzyl \\
\hline 15 & Butyl & $\begin{array}{l}\text { 3-(phthalimido-2-yl) } \\
\text { propyl }\end{array}$ & 26 & Phenyl & 2-piperidinoethyl \\
\hline 16 & Allyl & Ethyl & 27 & Phenyl & 2-morpholinoethyl \\
\hline 17 & Allyl & Allyl & 28 & Phenyl & $\begin{array}{l}\text { 3-(phthalimido-2-yl) } \\
\text { propyl }\end{array}$ \\
\hline
\end{tabular}

antiviral activity, all tested molecules have been classified into three groups: inactive- $(\mathrm{SI}<2)$, active- $(2 \leq \mathrm{SI}<10)$ and very active-types $(\mathrm{SI} \geq 10)$ [19]. Accordingly, compounds 5-9, 11, 15-18, 21, 22, 24, 25, 27 and 28 were active against CVB4. On the other hand, compound $\mathbf{5}$ has shown activity against HSV 1 and 2, while $\mathbf{2 4}$ was found to be active against HSV 1 . It may be noticed that the tested molecules $\mathbf{5}$ and $\mathbf{9}$ showed significant levels of high activity against CVB4, with SI values of 6.27 and 5.77, whereas 15, 21 and $\mathbf{2 4}$ were less active (3.60, 3.73 and 3.85 , respectively) with regard to ribavirin (16.38). However, 6, 7, 8, 11, 16, 17, 18, 22, 25, 27 and 28 exhibited moderate activity against CVB4, with SI values in the range of 2.05-3.31. Moreover, compound 5 demonstrated good activity against HSV-1 and HSV-2 (SI $=4.28$ and 5.18, respectively) and 24 was active against HSV-1 $(\mathrm{SI}=2.61)$ in relation to ribavirin (41.93 and 24.69).

In outlining the results in Table 2 and Fig. 1, it should be clarified that modifications on the lead structures 1-3 afforded new structural features (5-28) with a wide range of effects against the HSV and CVB4 viruses. For instance, $S$-alkylated products 7-28 exhibited significant activity against Coxsackie B4. In particular, compounds $7-9,11,15-18,21,22,24,25,27$ and 28 were more active than their parents 1-3. Moreover, variations in the type of the $N$-alkyl and $S$-alkyl (heteroalkyl) groups resulted in variations of the activity, in which compound 9 represented against CVB4 as the most active among the $S$-alkylated compounds $(\mathrm{SI}=5.57)$. Compounds 15, 21, 24 and 28 showed a pronounced activity against CVB4 (SI $=3.60,3.73,3.85$ and 3.31 , respectively). In regard to anti-herpes activity, compound $\mathbf{1}$ was inactive, but its $S$-alkylated products 7-15 exhibited slight activity. Similarly, the parents 2 and 3 appeared less active than their chemically transformed products 16-21 and 22-28, respectively. However, hydrazino products 5 and 6 offered more advantages in terms of activity against HSV and CVB4 viruses. Depending on the values of the SI-parameter, $\mathbf{5}$ gave rise to the greatest activity against HSV-1 (4.28), followed by HSV-2 (5.18) and CVB4 (6.27). Moreover, the presence of the butyl group at the " $R$ " position provided a significant effect against CVB4 and HSV viruses. This effect can be seen in both $S$-alkylated and hydrazino derivatives. However, the " $R_{1}$ " position requires a hydrophobic moiety to provide a selective antiviral activity against CVB4, as in compound 9. On the other hand, compound $\mathbf{5}$ exhibited a non-specific antiviral activity against CVB4 and HSV viruses. This effect also can be seen with compound $\mathbf{2 4}$ that has a 3-cyanobenzyl moiety at " $R_{1}$ " position but with a phenyl group instead of butyl at " $R$ " position.

To investigate the effect of the different variation of the original skeletons, a molecular docking experiment 
<smiles>[R1]Sc1nc2cc3ccccc3cc2c(=O)n1[R]</smiles><smiles>[R]n1c(=S)[nH]c2cc3ccccc3cc2c1=O</smiles><smiles>[R]n1c(NN)nc2cc3ccccc3cc2c1=O</smiles>

7-28 (R=butyl, allyl, phenyl)

1 ( $R=$ butyl)

2 ( $\mathrm{R}=$ allyl)

5 (R=butyl)

3 ( $\mathrm{R}=$ phenyl)

$6(\mathrm{R}=$ allyl)

4 ( $R=$ =cyclohexyl)

Scheme 1 Synthetic route for 2-thioxo-benzo[g]quinazolines (1-28)

Table 2 Antiviral activity against HSVand CVB4 of compounds (1-28) in terms of $\mathrm{CC}_{50}, \mathrm{EC}_{50}(\mu \mathrm{g} / \mathrm{mL})$ and SI

\begin{tabular}{|c|c|c|c|c|c|c|c|}
\hline \multirow[t]{2}{*}{ Cpd Nr. } & \multirow[t]{2}{*}{$\mathrm{CC}_{50}$} & \multicolumn{2}{|l|}{ HSV-1 } & \multicolumn{2}{|l|}{ HSV-2 } & \multirow{2}{*}{$\begin{array}{l}\text { CVB4 } \\
\mathrm{EC}_{50}\end{array}$} & \multirow[b]{2}{*}{ SI } \\
\hline & & $\mathrm{EC}_{50}$ & SI & $\mathrm{EC}_{50}$ & SI & & \\
\hline 1 & 115.9 & Inactive & Inactive & Inactive & Inactive & 272.4 & 0.43 \\
\hline 2 & 173.1 & 247.5 & 0.70 & 213.8 & 0.81 & 149.2 & 1.16 \\
\hline 3 & 376.5 & 428.1 & 0.88 & 361.6 & 1.04 & 342.4 & 1.10 \\
\hline 4 & 824.7 & 706.4 & 1.17 & 649.2 & 1.27 & 478.9 & 1.72 \\
\hline 5 & 3840 & 896.4 & 4.28 & 740.8 & 5.18 & 612.8 & 6.27 \\
\hline 6 & 261.4 & 224.5 & 1.16 & 208.9 & 1.25 & 102.9 & 2.54 \\
\hline 7 & 105.7 & 73.8 & 1.43 & 81.4 & 1.30 & 38.9 & 2.72 \\
\hline 8 & 218.5 & 147.1 & 1.49 & 159.6 & 1.37 & 93.6 & 2.33 \\
\hline 9 & 546.9 & 316.5 & 1.73 & 359.2 & 1.52 & 94.8 & 5.77 \\
\hline 10 & 198.9 & 162.7 & 1.22 & 184.3 & 1.08 & 124.1 & 1.60 \\
\hline 11 & 542.6 & 403.9 & 1.34 & 467.3 & 1.16 & 216.2 & 2.51 \\
\hline 12 & 83.7 & 74.12 & 1.13 & 65.9 & 1.27 & 56.4 & 1.48 \\
\hline 13 & 652.4 & 594.6 & 1.10 & 681.3 & 0.96 & 371.8 & 1.75 \\
\hline 14 & 221.8 & 197.3 & 1.12 & 176.4 & 1.26 & 116.8 & 1.90 \\
\hline 15 & 376.2 & 243.2 & 1.55 & 260.8 & 1.44 & 104.6 & 3.60 \\
\hline 16 & 934.2 & 582.9 & 1.60 & 624.6 & 1.50 & 316.4 & 2.95 \\
\hline 17 & 132.7 & 81.2 & 1.63 & 104.8 & 1.27 & 50.2 & 2.64 \\
\hline 18 & 183.4 & 149.8 & 1.22 & 140.5 & 1.31 & 89.5 & 2.05 \\
\hline 19 & 236.5 & 189.3 & 1.25 & 174.9 & 1.35 & 157.1 & 1.51 \\
\hline 20 & 465.3 & 369.1 & 1.26 & 402.9 & 1.15 & 287.6 & 1.62 \\
\hline 21 & 968.7 & 674.8 & 1.44 & 812.6 & 1.19 & 259.4 & 3.73 \\
\hline 22 & 127.3 & 76.3 & 1.67 & 89.4 & 1.42 & 41.2 & 3.09 \\
\hline 23 & 205.6 & 183.6 & 1.12 & 165.2 & 1.24 & 149.2 & 1.38 \\
\hline 24 & 169.1 & 64.7 & 2.61 & 112.3 & 1.51 & 43.9 & 3.85 \\
\hline 25 & 431.6 & 307.2 & 1.40 & 284.8 & 1.52 & 204.3 & 2.11 \\
\hline 26 & 681.2 & 498.2 & 1.37 & 514.6 & 1.32 & 395.6 & 1.72 \\
\hline 27 & 1034.8 & $>1000$ & Inactive & $>1000$ & Inactive & 475.3 & 2.17 \\
\hline 28 & 189.6 & 162.4 & 1.17 & 178.6 & 1.06 & 57.3 & 3.31 \\
\hline Acyclovir & 648.2 & 2.3 & 281.83 & 1.06 & 144.04 & - & - \\
\hline Ribavirin & 486.4 & 11.6 & 41.93 & 11.3 & 24.69 & 29.7 & 16.38 \\
\hline
\end{tabular}

Cells treated with DMSO (0.1\%) were used as a negative control, and its reading was subtracted from the readings of tested compounds. Statistics were calculated using one-way ANOVA 

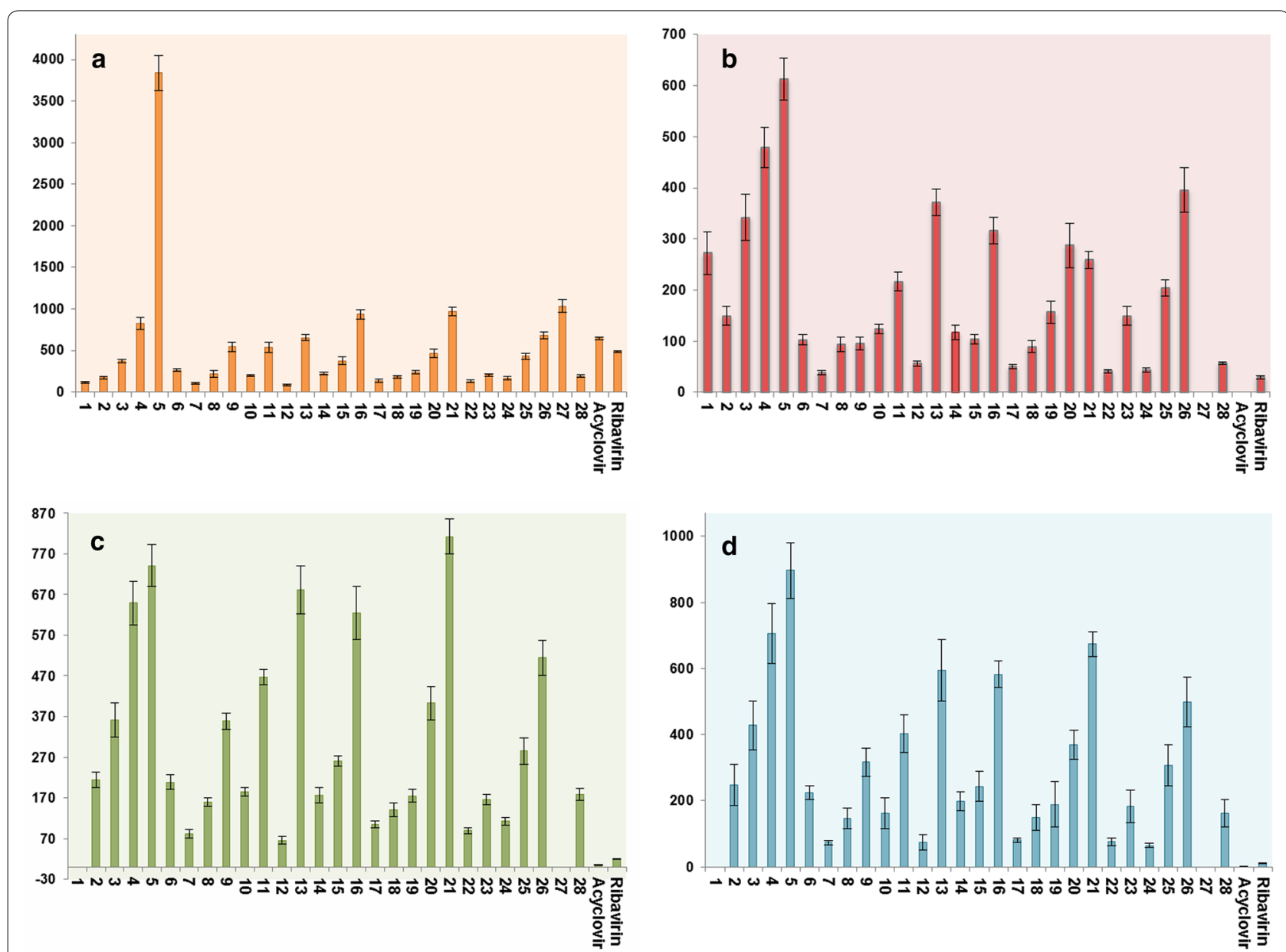

Fig. 1 Antiviral and cytotoxicity evaluation of the synthesized compounds $\mathbf{1 - 2 8}$ compared to ribavirin and acyclovir. $\mathbf{a}$ Cytotoxicity effect $\left(\mathrm{CC}_{50}\right)$. $\mathbf{b}$ Antiviral evaluation against CVB4 $\left(E_{50}\right)$. c Antiviral evaluation against HSV-2 $\left(E_{50}\right)$. d Antiviral evaluation against HSV-1 (EC ${ }_{50}$ ). All the values represented in $(\mu \mathrm{g} / \mathrm{mL})$

has been done with correlation to CVB4 2A proteinases. CVB4 2A proteinases perform essential roles involving viral polyprotein self-processing and shutting down of host-cell protein synthesis during viral replication. In addition, CVB4 2A proteinases also cleave heart muscle dystrophin, leading to cytoskeletal dysfunction and the symptoms of human-acquired dilated cardiomyopathy [20]. In silico docking experiments were performed for compounds 1-28 against the X-ray crystal structure of Coxsackievirus B4 2A proteinases (Protein Data Bank (PDB): 1Z8R) [20] using Molegro Virtual Docker software. Docking results were then evaluated by the MolDock score function, and hydrogen bond interactions between tested compounds and the target receptor were used for comparison between the tested and reference compounds [21]. Ribavirin (reference drug) forms eleven hydrogen bonds with amino acid residues at the active site: Tyr 89, Asn 19, Glu 88, Gln 95, Asp 39 and Thr 125, and generated a MolDock score of -100.84 (Fig. 2).

Compounds 1-6 had MolDock scores ranging from -81.42 to -84.81 (Table 3). These scores increased from -84.82 to -126.89 in compounds $7-28$, and reached the highest levels $(-124.852,-124.156$ and -126.899 ) in compounds $\mathbf{1 0}, \mathbf{1 8}$ and 24, respectively. However, compounds 10 and 18 have a 3-methoxybenzyl group at the " $R_{1}$ " position, but they are varied between each other with butyl group in compound 10 and allyl group in compound 18 at the "R" position. Even though, their MolDock scores were high but it did not enhance their antiviral activity. On the other hand, compound $\mathbf{2 4}$ that gave the highest MolDock score in this experiment has a phenyl group at " $R$ " position and 3-cyanobenzyl group at " $R_{1}$ " position. Compound 24 made three hydrogen bonds with the 


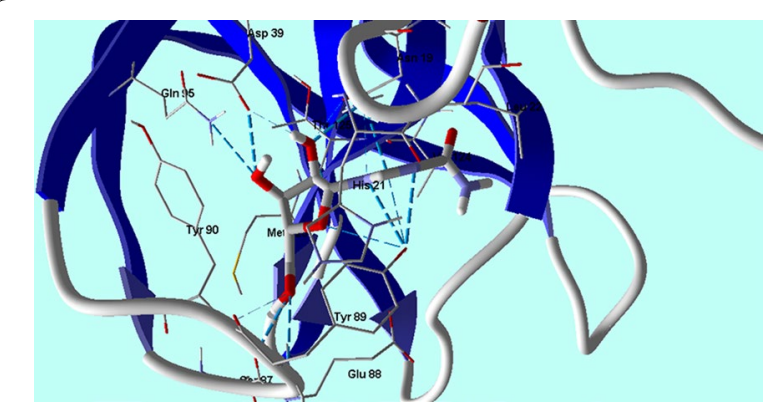

Fig. 2 Ribavirin shows hydrogen bonds interactions with CVB4 2A Proteinase enzyme (PDB: 1Z8R) active site

amino acid residues (Tyr 89, Asn 19 and Glu 88) with CVB4 2A Proteinase enzyme (PDB: 1Z8R) active site (Fig. 3). Interestingly, the para position of " $R_{1}$ " substituted benzyl group, such as compound 12, did not enhance the MolDock score than the meta position as in compound 10 and 18. This supports the notion that a hydrophobic moiety at the " $R$ " position is important for the protein binding and the wide range of antiviral activity against CVB4 and HSV. We propose that the phenyl group in compound $\mathbf{2 4}$ might participate in a non-polar staking interaction. Moreover, the quality of the docking process was attributed to the good overlapping of compound $\mathbf{2 4}$ with ribavirin in the active site (Fig. 4). Taking into account the preceding results, $S$-alkylated products 7-28 demonstrated good interaction with CVB4 with regard to the parent compounds (1-3), along with 9, 21 and 24 that indicate good relation with the biological results in Table 3.

\section{Methods}

\section{Mammalian cell line}

The source and methodology for preparation of the Vero cells were reported in details by Al-Salahi et collaborators [11]. The GHSV-UL46, G and E2 viral strains were used for the assay of HSV-1, HSV-2 and CVB4 viruses, respectively.

\section{Evaluation of the antiviral activity}

Screening of the antiviral was performed using MTT assay. According to the literature [11, 22, 23], the Vero cells were cultured, then treated with two-fold serial dilutions of the tested compounds, starting from $1000 \mu \mathrm{g} / \mathrm{mL}$ and diluting to about $2 \mu \mathrm{g} / \mathrm{mL}(1000,500,250,125,62.5$, $31.25,15.63,7.81,3.91,1.95 \mu \mathrm{g} / \mathrm{mL})$. Six wells were used for each concentration of the tested compound and three independent experiments were assessed, each containing four replicates per treatment [24]. Untreated Vero cell control and infection controls were made in the absence of tested compounds. Acyclovir and ribavirin were used as positive controls in this assay [25].

After incubating for $48 \mathrm{~h}$, the numbers of viable cells were determined by the MTT test. Briefly, the medium was removed from the 96-well plate and replaced with $100 \mu \mathrm{L}$ of fresh RPMI 1640 medium without phenol red, then $10 \mu \mathrm{L}$ of the $12 \mathrm{mM}$ MTT stock solution [5 mg of MTT in $1 \mathrm{~mL}$ of phosphate-buffered saline (PBS)] to each well, including the untreated controls. The 96-well plates were then incubated at $37{ }^{\circ} \mathrm{C}$ and $5 \% \mathrm{CO}_{2}$ for $4 \mathrm{~h}$. An $85 \mu \mathrm{L}$ aliquot of the medium was removed from the wells, and $50 \mu \mathrm{L}$ of dimethyl sulfoxide (DMSO) were added to each well, mixed thoroughly with the pipette, and incubated at $37{ }^{\circ} \mathrm{C}$ for $10 \mathrm{~min}$. Then, the optical density was measured at $590 \mathrm{~nm}$ with a microplate reader (Sunrise, Tecan U.S. Inc., USA) to determine the number of viable cells $[11,22,26]$.

The viral inhibition rate was calculated as follows:

$$
\begin{aligned}
& \text { Viral Inhibition Rate } \\
& \quad=[(\text { ODtv }- \text { ODcv }) /(\text { ODcd }- \text { ODcv })] \times 100 \%,
\end{aligned}
$$

where ODtv, ODcv and ODcd indicate the absorbance of the tested compounds with virus-infected cells, the absorbance of the virus control and the absorbance of the

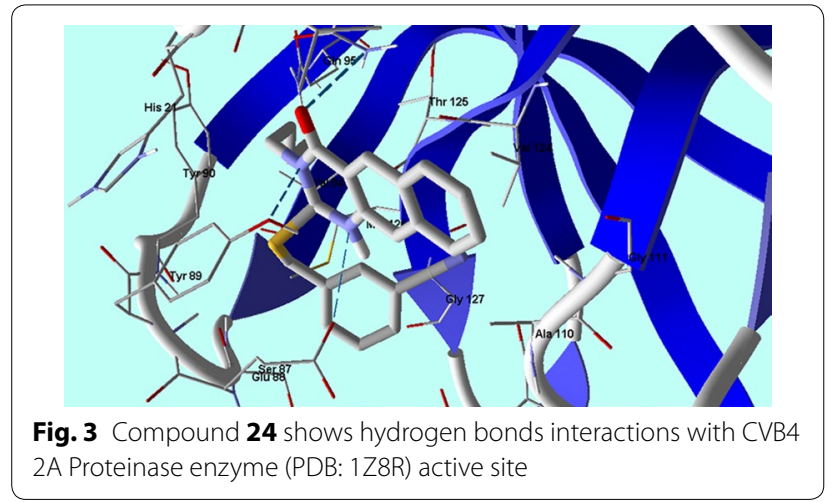

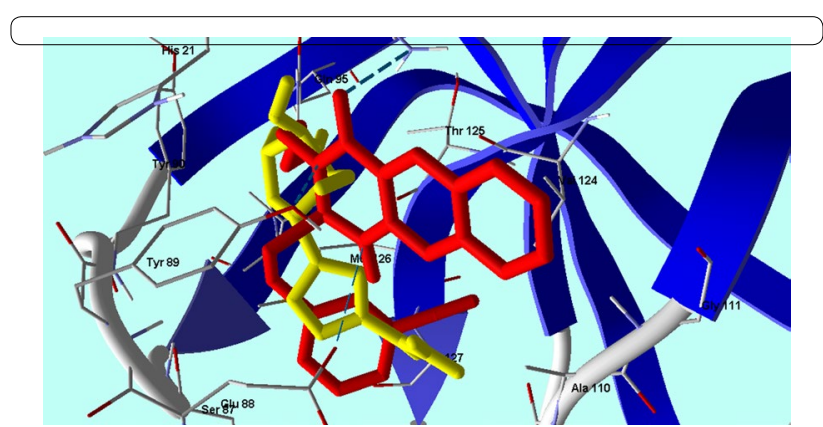

Fig. 4 Compound $\mathbf{2 4}$ superimposed with Ribavirin in CV B4 2A Proteinase enzyme (PDB: 1Z8R) active site 
Table 3 Molecular docking results of tested compounds (1-28)

\begin{tabular}{llllll}
\hline $\begin{array}{l}\text { Ligand } \\
\text { MolDock } \\
\text { score }\end{array}$ & $\begin{array}{l}\text { Rerank } \\
\text { score }\end{array}$ & Ligand & $\begin{array}{l}\text { MolDock } \\
\text { score }\end{array}$ & $\begin{array}{l}\text { Rerank } \\
\text { score }\end{array}$ \\
\hline $\mathbf{1}$ & -84.7301 & 11.9741 & $\mathbf{1 5}$ & -102.661 & 170.385 \\
$\mathbf{2}$ & -81.6688 & -54.7013 & $\mathbf{1 6}$ & -89.6801 & -49.3148 \\
$\mathbf{3}$ & -83.1126 & -64.3716 & $\mathbf{1 7}$ & -99.0106 & -61.5796 \\
$\mathbf{4}$ & -81.4295 & -47.6937 & $\mathbf{1 8}$ & -124.156 & -35.6187 \\
$\mathbf{5}$ & -84.4966 & -61.7217 & $\mathbf{2 0}$ & -108.311 & 3.82767 \\
$\mathbf{6}$ & -84.8156 & -57.6283 & $\mathbf{2 1}$ & -97.9703 & 146.694 \\
$\mathbf{7}$ & -97.1415 & -28.781 & $\mathbf{2 2}$ & -93.5541 & -43.7713 \\
$\mathbf{8}$ & -106.264 & -13.9656 & $\mathbf{2 3}$ & -86.1706 & 16.8665 \\
$\mathbf{9}$ & -109.555 & 16.3502 & $\mathbf{2 4}$ & -126.899 & -16.0488 \\
$\mathbf{1 0}$ & -124.852 & -41.5862 & $\mathbf{2 5}$ & -101.643 & -45.7134 \\
$\mathbf{1 1}$ & -101.561 & -24.4802 & $\mathbf{2 6}$ & -102.852 & 15.5337 \\
$\mathbf{1 2}$ & -112.213 & 10.1418 & $\mathbf{2 7}$ & -106.807 & -8.86485 \\
$\mathbf{1 3}$ & -98.2456 & 2.8343 & $\mathbf{2 8}$ & -84.8292 & 52.4014 \\
$\mathbf{1 4}$ & -98.3327 & -16.7182 & Ribavirin & -100.849 & -68.7835 \\
\hline
\end{tabular}

cell control, respectively. The $\mathrm{EC}_{50}$ was estimated with respect to the virus control from the graphic plots, using STATA modelling software and (SI) calculated from the ratio of $\mathrm{CC}_{50}$ to $\mathrm{EC}_{50}[11,26]$.

\section{Cytotoxicity evaluation using viability assay}

The procedure for seeding and incubation of Vero cells was explained in details in previous research [11, 23, 27]. After the end of the incubation period, the number of viable cells was determined by the MTT test. Briefly, the medium was removed from the 96-well plate and replaced with $100 \mu \mathrm{L}$ of fresh RPMI 1640 medium without phenol red, then $10 \mu \mathrm{L}$ of the $12 \mathrm{mM}$ MTT stock solution (5 mg of MTT in $1 \mathrm{~mL}$ of PBS) to each well including the untreated controls. The 96-well plates were then incubated at $37{ }^{\circ} \mathrm{C}$ and $5 \% \mathrm{CO}_{2}$ for $4 \mathrm{~h}$. An $85 \mu \mathrm{L}$ aliquot of the medium was removed from the wells, and $50 \mu \mathrm{L}$ of DMSO were added to each well, mixed thoroughly with the pipette, and incubated at $37{ }^{\circ} \mathrm{C}$ for $10 \mathrm{~min}$. Then, the optical density was measured at $590 \mathrm{~nm}$ with the microplate reader (Sunrise, Tecan U.S. Inc., USA) to determine the number of viable cells. Without added stain, all obtained findings were corrected for background absorbance detected in wells. In the absence of the tested compounds, treated samples were compared with the cell controls. All experiments were carried out in triplicate. The cytotoxicity of each tested compound was calculated [24, 25, 27, 28].
The percentage cell viability, calculated using Microsoft Excel $^{\circledR}$, is as follows:

$$
\begin{aligned}
& \% \text { Cell Viability }=\left[\left(\text { Mean }_{\mathrm{Abs}_{\text {control }}}-\text { Mean } \mathrm{Abs}_{\text {test metabolite }}\right) /\right. \\
& \text { Mean } \left.\mathrm{Abs}_{\text {control }}\right] \times 100 \% \text {, }
\end{aligned}
$$

where Abs equals the absorbance at $590 \mathrm{~nm}$. The STATA statistical analysis package was used for the dose response curve, which was used to calculate $\mathrm{CC}_{50}$.

\section{Data analysis}

Statistical analysis was done using a one-way ANOVA test [29]. All experiments and data analysis of the antiviral and cytotoxicity evaluations were carried out in RCMB, Al-Azhar University, Cairo, Egypt.

\section{Molecular docking}

The modelling studies were done by a PC with Intel $\odot$ Core $^{\mathrm{TM}}$ i7-3630 QM CPU (2.40 GHz, RAM 8 GB) operating under the Windows 7 Professional Operating System [11]. The modelling processes included several steps: first, download the 3D crystal structures of the Coxsackievirus B4 2A proteinase enzyme with $\mathrm{PDB}$ code $1 \mathrm{Z8R}$ (Brookhaven Protein Data) [20], and then load this into the Molegro Virtual Docker (MVD 2013.6.0 [Win32]) program (fully functional, free trial version with time limiting license; Molegro Virtual Docker (MVD 2013.6.0), Molegro Bioinformatics Solutions, Denmark, 2013; Thomsen and Christensen, 2006). ChemBio3D Ultra 10 [30] was used to draw the 3D structures of different ligands. Ligands were further optimized using a free version of Marvinsketch 4.1.13 (Marvinsketch, version 6.1.0, Chemaxon, Budapest, Hungary; http://www. chemaxon.com, 2013) with MM force field, and saved in Tripos mol2 file format. MolDock score functions were used with a $0.3 \mathrm{~A}^{\circ}$ grid resolution. Prior to the calculation of the MolDock scores of the tested compounds, the MVD software was benchmarked docking ribavirin [11].

\section{Authors' contributions \\ RA and MM made a significant contribution to acquisition of data, analysis, manuscript preparation. HAA analysed the data and revised the manuscript. HAG designed and performed the molecular docking study. RE revised and approved the final manuscript. All authors read and approved the final manuscript.}

\section{Author details}

${ }^{1}$ Department of Pharmaceutical Chemistry, College of Pharmacy, King Saud University, P. O. Box 2457, Riyadh 11451, Saudi Arabia. ${ }^{2}$ Department of Pharmacognosy, College of Pharmacy, King Saud University, P.O. Box 22452, Riyadh 11495, Saudi Arabia. ${ }^{3}$ Department of Pharmacognosy, Faculty of Pharmacy, Helwan University, Cairo 11795, Egypt. ${ }^{4}$ Chemistry of Natural Products 
Group, Center of Excellence for Advanced Sciences, National Research Center, Dokki, Cairo 12622, Egypt.

\section{Competing interests}

The authors declare that they have no competing interests.

\section{Funding}

The authors extend their appreciation to the Deanship of Scientific Research at King Saud University for funding this work through research group No RG-1435-068.

Received: 26 November 2015 Accepted: 7 April 2016

Published online: 19 April 2016

\section{References}

1. Barton S (2005) The role of anti-HSV therapeutics in the HIV-infected host and in controlling the HIV epidemic. Herpes 12:15-22

2. Kang Y, Chatterjee NK, Nodwell MJ, Yoon JW (1994) Complete nucleotide sequence of a strain of coxsackie B4 virus of human origin that induces diabetes in mice and its comparison with nondiabetogenic coxsackie B4 JBV strain. J Med Virol 44:353-361

3. De Oliveira A, Prince D, Lo C-Y, Lee LH, Chu T-C (2015) Antiviral activity of the aflavin digallate against herpes simplex virus type 1. Antiviral Res 118:56-67

4. Fatahzadeh M, Schwartz RA (2007) Human herpes simplex virus infections: Epidemiology, pathogenesis, symptomatology, diagnosis, and management. J Am Acad Dermatol 57:737-763

5. Crowell RL, Landau BJ (1997) A short history and introductory background on the coxsackieviruses of group B. Curr Top Microbiol Immunol 233:1-11

6. Whitley RJ, Roizman B (2001) Herpes simplex virus infections. Lancet 357:1513-1518

7. Roizman B, Pellett PE (2001) The Family Herpesviridae: A Brief Introduction. In: Knipe DM, Howley PM (eds) Fields Virology, 4th edn. Lippincott, Williams and Wilkins, Philadelphia, pp 2381-2396

8. Knipe DM, Cliffe A (2008) Chromatin control of herpes simplex virus lyticand latent infection. Nat Rev Microbiol 6:211-221

9. Van Lier RA, ten Berge IJ, Gamadia LE (2003) Human CD8(+) T-cell differentiation in response to viruses. Nat Rev Microbiol 3:931-939

10. Jaime MFV, Redko F, Muschietti LV, Campos RH, Martino VS, Cavallaro LV (2013) In vitro antiviral activity of plant extracts from Asteraceae medicinal plants. Virol J 10:245

11. Al-Salahi R, Alswaidan I, Ghabbour HA, Ezzeldin E, Elaasser M, Marzouk M (2015) Docking and antiherpetic activity of 2-aminobenzo[de]-isoquinoline-1,3-diones. Molecules 20:5099-5111

12. Al-Salahi R, Marzouk M, Alswaidan I, Al-Omar M (2013) Antiviral activity of 2-phenoxy-4H-[1,2,4]triazolo[1,5-a]quinazoline derivatives. Life Sci J 10:2164-2169

13. Al-Salahi R, Al-Omar M, Alswaidan I, Marzouk M, Alsenousy W, Amr AE (2015) Antiviral activities of some synthesized methylsulfanyltriazoloquinazoline derivatives. Res Chem Intermed 41:151-161

14. Pendergast W, Johnson JV, Dickerson SH, Dev IK, Duch DS, Ferone R, Hall WR, Humphreys J, Kelly JM, Wilson DC (1993) Benzoquinazoline inhibitors of thymidylate synthase: enzyme inhibitory activity and cytotoxicity of some 3-amino- and 3-methylbenzo[f]quinazolin-1(2H)-ones. J Med Chem 36:2279-2291

15. Maddry JA, Chen $X$, Jonsson CB, Ananthan S, Hobrath J, Smee DF, Noah JW, Noah D, Xu X, Jia F, Maddox C, Sosa MI, White EL, Severson WE (2011) Discovery of novel benzoquinazolinones and thiazoloimidazoles, inhibitors of influenza $\mathrm{H} 5 \mathrm{~N} 1$ and $\mathrm{H} 1 \mathrm{~N} 1$ viruses, from a cell-based high-throughput screen. J Biomol Screen 16:73-81

16. Suthakaran R, Nagarajan G, Balasubramaniam V, Suganthi K, Velrajan G (2005) Synthesis and antimicrobial activity of [(arylpyrazolobenzopyranyl) methyl]benzoquinazolin-ones. Indian J Heterocycl Chem 14:201-204

17. Markosyan Al, Torshirzad NM, Shakhbazyan GH, Arsenyan FG (2014) Synthesis and antineoplastic properties of 3-substituted 5,5-dimethylbenzo[h] quinazolin-4(3H)-ones. Pharm Chem J 47:651-654

18. Al-Salahi R, El Dib RA, Marzouk M (2015) Synthesis and in vitro cytotoxicity evaluation of new 2-thioxo-benzo[g]quinazolin-4(3H)-one derivatives. Heterocycles 91:1735-1751

19. Garett R, Romanos MTV, Borges RM, Santos MG, Rocha L, da Silva AJR (2012) Antiviral activity of a flavonoid fraction from Ocotea notata leaves. Braz J Pharmacogn 22:306-313

20. Baxter NJ, Roetzer A, Liebig H-D, Sedelnikova SE, Hounslow AM, Skern T, Waltho JP (2006) Structure and dynamics of coxsackievirus B4 2A proteinase, an enyzme involved in the etiology of heart disease. J Virol 80:1451-1462

21. Yang JM, Chen CC (2004) GEMDOCK: a generic evolutionary method for molecular docking. Proteins 55:288-304

22. Hu JM, Hsiung GD (1989) Evaluation of new antiviral agents I: in vitro prospective. Antiviral Res 11:217-232

23. Vijayan P, Raghu C, Ashok G, Dhanaraj SA, Suresh B (2004) Antiviral activity of medicinal plants of Nilgiris. Indian J Med Res 120:24-29

24. Dargan DJ (1998) Investigation of the anti-HSV activity of candidate antiviral agents. In: Brown SM, MacLean AR (eds) Methods in molecular medicine, herpes simplex virus protocols, vol 10. Humana Press Inc, Totowa, pp 387-405

25. Mosmann T (1983) Rapid colorimetric assay for cellular growth and survival: application to proliferation and cytotoxicity assays. J Immunol Methods 65:55-63

26. Zandi K, Zadeh MA, Sartavi K, Rastian Z (2007) Antiviral activity of Aloe vera against herpes simplex virus type 2: an in vitro study. Afr J Biotechnol 6:1770-1773

27. Wilson AP (2000) Cytotoxicity and viability assays in animal cell culture: a practical approach, 3rd edn. In: Masters JRW (ed), Oxford University Press, Oxford

28. Vega-Avila E, Pugsley MK (2011) An overview of colorimetric assay methods used to assess survival or proliferation of mammalian cells. Proc West Pharmacol Soc 54:10-14

29. Castilla-Serna L, Cravioto J (1999) Simply statistic for health investigation, 1st edn. Trillas, Mexico

30. Kerwin SM (2010) ChemBioOffice Ultra 2010 suite. J Am Chem Soc $132: 2466-2467$

\section{Submit your manuscript to a SpringerOpen ${ }^{\oplus}$ journal and benefit from:}

- Convenient online submission

- Rigorous peer review

- Immediate publication on acceptance

- Open access: articles freely available online

- High visibility within the field

- Retaining the copyright to your article

Submit your next manuscript at $>$ springeropen.com 